\title{
Does young adults' life satisfaction promote tolerance towards immigrants? The role of political satisfaction and social trust
}

\author{
Liliia Korol ${ }^{1,2,3}$ (D) Pieter Bevelander ${ }^{2}$ \\ Accepted: 25 May 2021 / Published online: 28 May 2021 \\ (C) The Author(s) 2021
}

\begin{abstract}
Much prior research relies on the idea that antipathy towards immigrants is primarily driven by natives' perceptions of the threat that immigrants represent to their economic, cultural or national well-being. Yet little is known about whether subjective wellbeing affects attitudes toward immigrants. This study aimed to examine whether life satisfaction would foster tolerance towards immigrants over time via the indirect influence of political satisfaction and social trust. The sample comprised young native adults $(N=1352 ; M$ age $=22.72 ; S D=3.1)$ in Sweden. The results revealed that young adults who were satisfied with important life domains were more likely to extend their satisfaction towards the political system, which consequently resulted in a generalised expectation of trustworthiness and a widening of their circles of trusted others. This then translates into more positive attitudes toward immigrants. The findings provide evidence that it is the causal relationship between political satisfaction and social trust (rather than social trust in itself) which promotes the positive impact of life satisfaction on tolerance towards immigrants. The study highlights that fostering political satisfaction and social trust may play an important role in shaping young people's positive attitudes towards immigrants.
\end{abstract}

Keywords Young adults $\cdot$ Tolerance $\cdot$ Life satisfaction $\cdot$ Political satisfaction $\cdot$ Social trust $\cdot$ Attitudes towards immigrants

\section{Introduction}

A long-established tradition in social psychological research (e.g., Branscombe \& Wann, 1992; Brown, 2011) suggests that negative life experiences (e.g., financial hardship, feelings of life insecurity) can increase negative attitudes toward outgroups. In a similar vein, relative deprivation theory (Walker \& Smith, 2002) postulates that, when people confront negative life circumstances, they tend to attribute them to minority-group members, particularly those who appear to be competing for resources or are seen to be the cause of their deprivation (such as immigrants; Jetten et al., 2015). Intuitively, when individuals experience high subjective well-being - and satisfaction with important life domains in

Liliia Korol

liliia.korol@udg.edu

1 Department of Psychology, Faculty of Psychology and Education, University of Girona, Plaça Sant Domènec, 9, 17004 Girona, Spain

2 Malmö Institute for Studies of Migration, Diversity and Welfare, Malmö University, Malmö, Sweden

3 National University of Ostroh Academy, Ostroh, Ukraine particular - they should be more inclined to develop positive outgroup attitudes. However, is it true that life satisfaction is connected to tolerance towards immigrant-origin individuals? In the present study, we propose that high life satisfaction promotes tolerance towards immigrants over time via the indirect influence of political satisfaction and social trust. We utilise a longitudinal research design to test our expectations in a community sample of young native adults in Sweden.

Integrating theoretical premises of positive and cognitive psychological paradigms, we argue that high life satisfaction makes individuals more likely to misattribute their positive cognitions and affective states to normatively unrelated judgments, such as evaluative perceptions of and beliefs about outgroup members, including those of immigrant-origin (e.g., Tenenbaum et al., 2018). Moreover, we assume that high life satisfaction may translate into young people's tolerance towards immigrants via their increased political satisfaction and sequentially increased social trust. Specifically, we theorise that native majority youth who experience high levels of life satisfaction may reciprocate by demonstrating satisfaction with democracy and trust of political institutions (e.g., Esaiasson et al., 2019; Mattila \& Rapeli, 2018; Wroe, 2014) which, in turn, may lead to a broader generalised expectation of trustworthiness and the widening of their circles of trusted 
others (e.g., Helliwell \& Putnam, 2004; Valenzuela et al., 2009; Zanin, 2017), thus leading to positive attitudes towards immigrants.

We contribute to the literature in a number of ways. First, contrary to the majority of studies in the field, we focus on positive (rather than negative) attitudes towards immigrants. Given that tolerance cannot simply be predicted by the absence of prejudicial and xenophobic attitudes and should be analysed as a separate construct (e.g., Korol, 2019; Korol et al., 2018; van Zalk et al., 2013), it is important to identify the specific factors that impact on its development. Second, we demonstrate that subjective well-being, and life satisfaction in particular, has an important role to play in promoting favourable attitudes towards immigrants. Prior research has primarily sought to explain (negative) attitudes towards immigrants through the lens of the threat perceptions that they represent to an individual economic (e.g., Hainmueller \& Hiscox, 2007; Schneider, 2008; Semyonov \& Glikman, 2009) or cultural well-being (e.g., McLaren, 2003; McLaren \& Johnson, 2007; Sides \& Citrin, 2007) and thus has largely ignored the role of subjective well-being in this process. A third and related contribution is that we examine the underlying mechanisms in the relationship between life satisfaction and tolerance towards immigrants. Our findings reveal that it is the causal relationship between political satisfaction and social trust that translates positive effects of life satisfaction into tolerance towards immigrants. Fourth, we utilise a longitudinal research design to test our expectations from the longterm perspective and examine all the processes over time. Finally, we zoom out on native majority young adults and attempt to extend our understanding of what shapes positive attitudes towards immigrants during this important developmental period.

This discussion is particularly important given that the increasing global migration to Europe - and to Sweden in particular - over the last half-century has diversified earlier, more homogenous, populations. Specifically, in the latest update by Statistics Sweden (2020), about $20 \%$ of the Swedish population in 2019 were foreign-born and more than a third had either on or two parents born abroad. This diversity is not perceived by everyone as positive and, although antiimmigrant sentiment in opinion polls has been largely stable over time (Bevelander \& Hellström, 2019; Demker, 2014), during the last 20 years anti-immigrant voices have been louder in public debate and there has been a gradual increase in people voting for populist anti-immigrant parties. Recent research points to the end of Swedish exceptionalism, which was associated with the previous, relatively generous, Swedish path and the absence of any populist radical party in the national parliament. This is, obviously, no longer the case (Emilsson, 2018; Rydgren \& van der Meiden, 2019). Moreover, although Sweden has relatively high levels of social and political trust - what is called a high-trust society
(Rothstein, 2001) - these parties seem to attract Swedish voters with lower general levels of trust (Bélanger \& Nadeau, 2005). Finally, Sweden is also among those countries where citizens indicate higher than average levels of life satisfaction in the EU (Eurostat, 2020). Taken together, it is vital to invest more into understanding how positive attitudes towards immigrants might be promoted, particularly among young people who will determine the societies of tomorrow.

The present paper proceeds as follows: we first outline the theoretical background to our study by presenting the arguments that link life satisfaction with tolerance towards immigrants. We then theorise about the potential mediating role of political satisfaction and social trust in this relationship, before providing information on our methodology and presenting the empirical results of the study. Finally, we conclude by discussing our findings as well as highlighting their implications and contributions.

\section{Life Satisfaction and Outgroup Attitudes}

Much prior research on the role of life satisfaction - and individual well-being more broadly - in affecting outgroup attitudes has predominantly focused on prejudice and xenophobia. This body of research commonly relies on the idea that antipathy and antagonism towards immigrants are primarily driven by natives' perceptions of the threat that immigrants represent to their economic (e.g., Hainmueller \& Hiscox, 2007; Schneider, 2008; Semyonov \& Glikman, 2009), cultural (e.g., McLaren, 2003; McLaren \& Johnson, 2007; Sides \& Citrin, 2007) or national (e.g., Ariely, 2012; Pryce, 2018) well-being. At the same time, limited attention has been paid to whether subjective well-being has any role to play in shaping outgroup attitudes - and tolerance towards immigrants in particular. As far as we are aware, only two studies have aimed to examine the relationship between subjective wellbeing and attitudes toward immigrants, studies which provided inconsistent findings. Specifically, Sirgy and his colleagues (Sirgy et al., 2018) showed that individuals (i.e., Germans aged between 18 and 70) who experienced high levels of subjective ill-being (i.e., low levels of subjective well-being) were likely to be more Islamophobic. By contrast, Gordon (2018) found that life satisfaction was not related to proimmigrant sentiments among a nationally representative probability sample in South Africa (aged 16 and over). In addition, prior studies that included life satisfaction in their analyses as a control variable (e.g., Lancee \& Sarrasin, 2015; McLaren, 2003; Quillian, 1995) and a proxy indicator for personal threat (McLaren, 2003) and social alienation (Sides \& Citrin, 2007) reported a weak or insignificant association with attitudes towards immigrants. Taken together, we are still very limited in our understanding of whether life satisfaction has any role to play in shaping tolerance towards immigrants. 
So why might individuals with high life satisfaction be more inclined to have positive attitudes towards immigrants? To explain how life satisfaction can lead to tolerance towards immigrants, we draw on two bodies of literature - positive and cognitive psychology. We argue that positive emotions and feelings of happiness resulting from satisfaction with important life domains and life as a whole make individuals more prone to adopt favourable attitudes toward immigrants. Specifically, recent research in positive psychology provides some evidence that greater life satisfaction generates positive cognition and affective states. For instance, Vittersø and Søholt (2011) showed that life satisfaction predicted feelings of pleasantness (a composite index of contentment, enjoyment and happiness) among young adults (aged between 18 and 31) in Norway. Relatedly, Unanue and his colleagues (Unanue et al., 2019) found that people who were more satisfied with their lives were more likely to appreciate the positive in life and, in particular, to feel a strong sense of gratitude.

At the same time, the cognitive psychology literature suggests that individuals' affective states and emotions have strong effects on cognition and may influence normatively unrelated judgments (see, for example, Forgas \& George, 2001; Isen \& Baron, 1991). Moreover, as postulated by the affect-as-information model (Schwarz \& Clore, 1988), people tend to misattribute their emotional feelings to judgements when the cause of these judgments - such as the evaluative judgement of outgroups - is complex or affective in nature (Schwarz, 1990).

In line with these arguments, a recent experimental study by Tenenbaum and her colleagues (Tenenbaum et al., 2018) showed that youth (16- to 21-year-olds) who were induced to feel happiness demonstrated more tolerant attitudes toward asylum-seeking young people than did those induced to feel fear or no emotions. In a similar vein, in research based on European Social Survey data, Panno (2018) showed that individuals who reported higher levels of happiness also demonstrated more positive attitudes toward immigrants, compared to those with lower levels of happiness.

Integrating these theoretical perspectives and empirical findings, we argue that, by generating positive feelings and emotional states, life satisfaction may influence how native young adults perceive immigrants and may lead to more favourable attitudes toward this group - a group frequently viewed as a threat to natives' cultural and national hegemony (Sides \& Citrin, 2007). Moreover, we assume that political satisfaction and social trust will have important roles to play in mediating the relationship between life satisfaction and tolerance towards immigrants.

\section{The Role of Political Satisfaction}

Prior research has provided support for the role of political satisfaction in the link between life satisfaction and attitudes towards immigrants. For instance, Hooghe (2012) demonstrated that Belgian citizens (aged 18 and over) who reported high levels of satisfaction with the different life domains (e.g., health, leisure time, professional life) were more likely to be satisfied with the way in which democracy worked in Belgium and with the type of society in which they lived. Similarly, Esaiasson and his colleagues (Esaiasson et al., 2019) showed that life satisfaction was strongly related to democratic satisfaction across European countries, over and above the confounding factors at country and individual levels. Furthermore, the researchers also found that people who had experienced a critical life event (i.e., the termination of a close personal relationship) reported lower levels of support for the government and that this support-undermining effect was mediated by decreases in life satisfaction.

One possible way to explain the link between life satisfaction and political satisfaction is to view the latter as a contractual relationship between the individual and the political system. According to psychological contract theory, contractual relationships function as an analytical tool that links citizens and their schemas (i.e., attitudes, beliefs) to the larger social structures in which they are situated (for further discussion, see Rubin, 2012). This theoretical perspective assumes that individuals extend their support to a political system only when they feel that they are receiving a certain level of benefits from it (e.g., security, a reasonable level of material wellbeing) and decent life conditions that meet their expectations (see, for example, the happiness contract model - Esaiasson et al., 2019 - and the psychological-democratic trust contract, Mattila \& Rapeli, 2018; Wroe, 2014). Thus, when native young adults experience high levels of satisfaction with important life domains, they may reciprocate by displaying trust for political institutions as well as satisfaction with democracy in the country and its political actors.

Prior research also provides some evidence that the extent to which individuals are satisfied or dissatisfied with the political system in their country and with the functioning of democracy in general is linked to their attitudes towards immigrants. For instance, a large-scale youth survey in 14 European countries (Mierina \& Korolyeva, 2015) showed that xenophobic, welfare chauvinistic and exclusionary attitudes toward immigrants were more widespread among youth (aged 16-25) who had low political trust as well as little interest in and understanding of politics. Relatedly, a recent study by Aschauer (2016), based on a large-scale dataset from the European Social Survey, found that individuals who reported higher levels of political disenchantment (e.g., distrust in politicians and political parties and dissatisfaction with the national government and the way in which democracy works in the country) were more likely to perceive immigrants as a threat, especially in Western Europe. Altogether, these findings suggest that political satisfaction might function as an important underlying mechanism in the relationship between 
life satisfaction and positive attitudes towards immigrants. Yet, to the best of our knowledge, no study has attempted to examine the mediating role of political dissatisfaction in the link between life satisfaction and tolerance towards immigrants.

\section{The Role of Social Trust}

Social trust may also mediate the relationship between life satisfaction and attitudes towards immigrants. As postulated by the broaden-and-build theory (Fredrickson, 2001), experiencing life satisfaction triggers positive emotions, which broaden an individual's world view and view of him/ herself and, thus, lead to better social relations and skills. In other words, when people are satisfied with important life domains and their life as a whole, they tend to shift their attention away from themselves and towards others and actively engage in prosocial behaviour (Aknin et al., 2018; Lyubomirsky et al., 2005; Oishi et al., 2007) that stimulates the building of trusting relationships with others (Brehm \& Rahn, 1997; Putnam, 2000). Supporting these arguments, existing empirical research (e.g., Helliwell \& Putnam, 2004; Valenzuela et al., 2009; Zanin, 2017) has found life satisfaction to be positively associated with general interpersonal trust. For instance, using cross-sectional data from a national survey in Italy, Zanin (2017) found that people who reported high levels of life satisfaction were more likely to report higher social trust. Relatedly, by conducting five experimental studies, Dunn and Schweitzer (2005) showed that people who experienced happiness were more likely to display interpersonal trust.

Prior research has also provided compelling evidence that social trust leads to positive attitudes towards immigrants. In particular, a study by Herreros and Criado (2009), employing data from the European Social Survey across 16 countries, found that individuals with higher levels of social trust had more positive attitudes towards immigrants, above and beyond other relevant determinants of a native individual's opinions on immigration (e.g., levels of unemployment, percentage of foreign population). Recent research also based on a large-scale dataset from the European Social Survey covering 21 countries (van Linden et al., 2017) showed that people who reported high generalised trust were less prone to exhibit antiimmigrant sentiments. These findings suggest that social trusters extend their positive worldviews towards different members of society and widen their circles of trusted others to also include immigrant-origin individuals. Hence, it is possible that social trust may pave the potential way through which life satisfaction may promote tolerance towards immigrants.

Although social trust has been considered as an antecedent to rather than the outcome of supporting orientations towards the political system (Newton et al., 2018; Putnam, 2000;
Zmerli \& Newton, 2008), the opposite causal direction of this relationship has also been established in the literature (Brehm \& Rahn, 1997; Kumlin \& Rothstein, 2005). As argued by Sønderskov and Dinesen (2016), the fairness and effectiveness of political and governmental institutions provide important clues about the norms of others and form the basis for generalised expectations of the trustworthiness of others. Prior empirical research has echoed this theoretical perspective and found strong associations between attitudes supporting both democracy and the political system and social trust (e.g., Newton \& Zmerli, 2011; Rothstein \& Stolle, 2008; Sønderskov \& Dinesen, 2014; You, 2012). More recently, utilising two Danish panel surveys, Sønderskov and Dinesen (2016) provided strong evidence that institutional trust can exercise a causal impact on social trust, whereas the evidence for a reverse causal link was limited. Additionally, a study based on a national survey in China (Tao et al., 2014) showed that people who reported higher levels of political trust were more inclined to exhibit greater social trust.

Taken together, it might be expected that political satisfaction and social trust would mediate the relationship between life satisfaction and tolerance towards immigrants in a causally connected manner. Specifically, it is plausible that native individuals who are satisfied with their important life domains and life as a whole will be more likely to exhibit higher levels of political satisfaction and, consequently, social trust which, in turn, will make them more inclined to hold positive attitudes towards immigrants. Nonetheless, no research to date has focused on understanding whether political satisfaction and social trust have any role to play in the link between life satisfaction and tolerance towards immigrants.

\section{The Present Study}

The present study is designed to understand how life satisfaction might promote tolerance towards immigrants among native majority young adults over time. Finding meaning in life and experiencing satisfaction with important life domains have been established as essential developmental tasks in young adulthood (Arnett, 2015; Mayseless \& Karen, 2014). Moreover, given the evidence suggesting that outgroup attitudes continue to crystallise further through adulthood (Henry $\&$ Sears, 2009), we decided to focus on native young adults and have attempted to extend our understanding of the role of life satisfaction in shaping positive attitudes towards immigrants during this important developmental period. Specifically, we examined whether political satisfaction and social trust would mediate the over-time relationship between life satisfaction and tolerance towards immigrants in a causally connected manner. We hypothesised that life satisfaction positively affects young people's tolerance towards immigrants via their increased political satisfaction and sequentially increased social trust. In order to test these relationships, we 
used a longitudinal design and followed three age cohorts of native majority young adults (aged 20, 22 and 26 years) over a period of two years.

\section{Method}

\section{Participants}

The data for the present study were taken from a large longitudinal survey - the Political Socialization Program (Amnå et al., 2009), conducted in a medium-sized Swedish city of about 137,000 inhabitants. The city is similar to the national average in its population density, levels of unemployment and income and its share of the immigrant population (Statistiska Centralbyrån, 2019). Our sample consisted of three age cohorts of young adults $(20,22$ and 26 years old) who were followed biannually over a period of four years.

The target sample comprised approximately 1000 individuals in each age group, who were randomly selected from a list, provided by the county, of all 20-26-year-olds living in the city. The questionnaire was mailed to the target sample, together with a personalised link to the online version of the questionnaire. The participants received information about the voluntary nature of their participation and the assurance of the confidentiality of the answers provided. The respondents received a gift card of $28 €$ for their participation in the study. All the procedures were approved by the [removed for masked review].

For the purposes of the present study, we focused only on young adults of native origin and excluded those with an immigrant background (i.e., with at least one parent born outside Sweden). After processing the data, the final analytic sample was made up of 1378 individuals: 479 aged 20, 420 aged 22 and 479 aged 26 (see Fig. 1). Taken as a whole, $57.3 \%$ were young females. Regarding education level, $20.7 \%$ of the respondents finished vocational high school, $40.7 \%$ finished academic high school and $27.8 \%$ finished college or university. A majority of young adults reported that they had moved away from home and had no children (80.6 and $91.4 \%$ respectively). In response to a question about their civil status, $36.9 \%$ said that they were married/co-habiting, $19.7 \%$ mentioned that they had a partner/partner in a separate residence and $43.1 \%$ reported that they were single.

\section{Measures}

Life Satisfaction Youth were asked to report on how satisfied or dissatisfied they were with the following: their relationship with their parents and friends and their private finances, home, education and life as a whole. The response scale ranged from 1 (Totally dissatisfied) to 7 (Totally satisfied). Higher scores indicated greater life satisfaction (Cronbach's $\alpha_{T 1}=0.78$ ).
Political Satisfaction In order to assess young adults' political satisfaction, we focused on the following two dimensions: 1) political trust in the parliament and the government; 2) satisfaction with democracy and political actors. The first dimension was measured via two items concerning the degree of their institutional trust in the parliament and the government, taken from a seven-item scale on political institutions. Responses were given on a 4-point Likert-type scale, ranging from 1 (No trust at all) to 4 (A lot of trust). The second dimension was assessed via the following two questions: 'On the whole, how satisfied are you with the way democracy works in Sweden?' and 'How satisfied are you with the way in which the sitting government is handling its tasks?' The response scale ranged from 1 (Not at all satisfied) to 4 (Very satisfied). Higher scores indicated a greater degree of political satisfaction (Cronbach's $\alpha_{\mathrm{T} 1}=0.84$ ). In addition, confirmatory factor analysis demonstrated that these four items loaded on one factor with the factor loadings ranging between 0.77 and 0.91 .

Social Trust Young adults were asked to report on their social trust by assessing the two items: 'Most people can be trusted' and 'Most people are fair and don't try to exploit you'. The response scale ranged from 1 (Doesn't apply at all) to 5 (Applies perfectly). The correlation between the two items was 0.75 . Higher scores indicated greater social trust (Cronbach's $\alpha_{\mathrm{T} 1}=0.78$ ).

Tolerance Tolerance towards immigrants was assessed via three items adapted from prior research on inter-group attitudes (van Zalk et al., 2013; van Zalk \& Kerr, 2014). The respondents were presented with the stem question 'What are your views on people who have moved here from other countries?' and were asked to rate items on a four-point Likert-type scale, ranging from 1 (Does not apply at all) to 4 (Applies very well). The items included: 'Our culture gets enriched when people from other countries move here', 'That people move to Sweden is good for the Swedish economy' and 'In the future, Sweden will be a country where there are exciting encounters between people from different parts of the world'. Higher scores indicated greater tolerance towards immigrants $\left(\right.$ Cronbach's $\left.\alpha_{\mathrm{T} 1}=0.80, \alpha_{\mathrm{T} 2}=0.81\right)$.

Control Variables In the present study, we controlled for gen$\operatorname{der}(1=$ female $)$, educational level and socio-economic status (SES).

Educational level. Youth's educational level was measured by a question about their achieved education, ranging from 1 (Did not finish compulsory school) to 7 (University college/university, three years or more).

Perceived socio-economic status. To assess how young adults perceived their socio-economic status, we asked them 
Fig. 1 Flowchart of the study design and participants

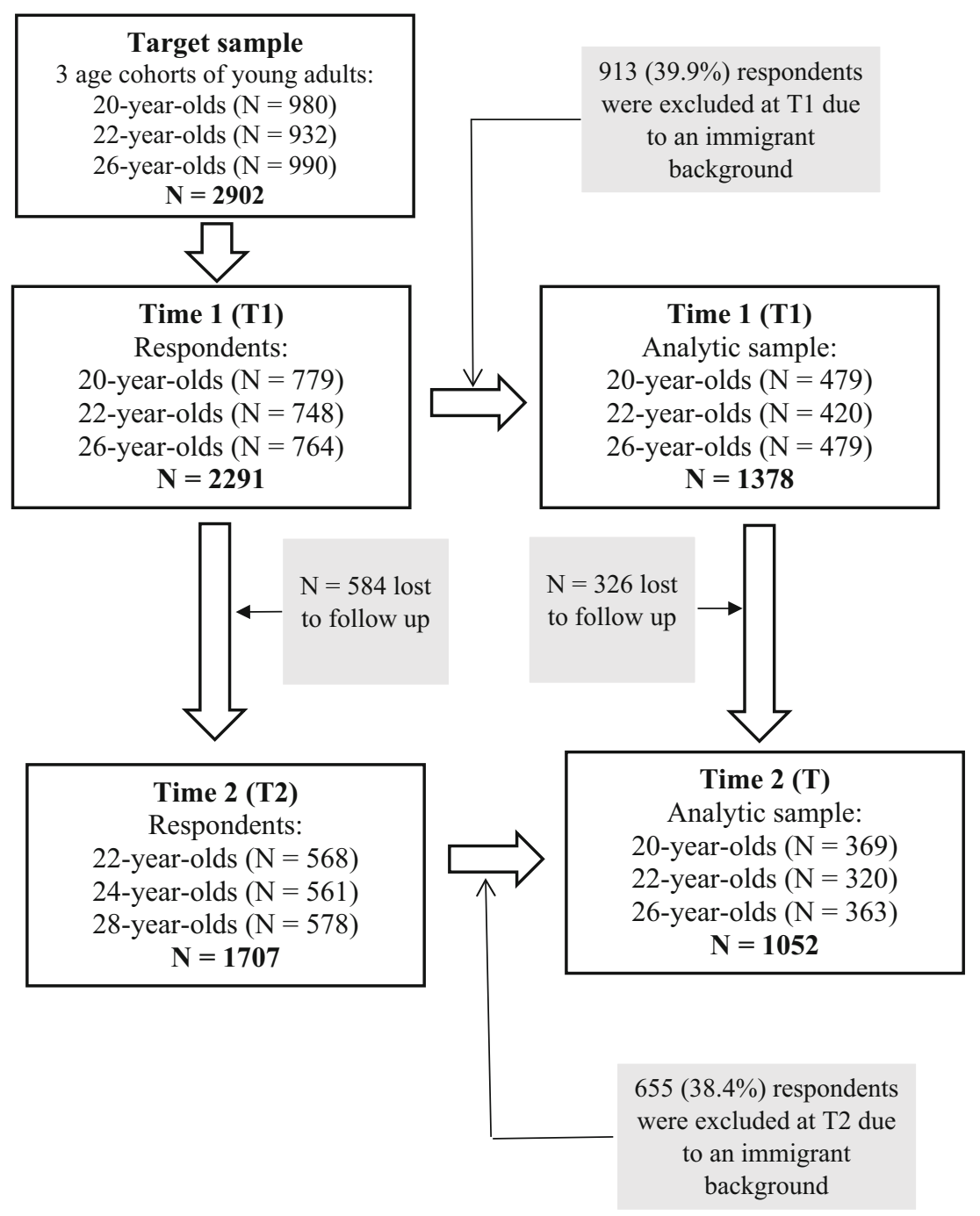

if they ever had difficulty in handling their ongoing expenses (for food, rent, other household items, etc.; 1 = 'Yes', $2=$ 'No').

\section{Attrition Analysis}

We conducted a logistic regression analysis to examine whether attrition from Time 1 (T1) to Time 2 (T2) was due to any systematic bias. We regressed attrition (dropout $=0$, retention $=1$ ) on the young adults' demographic characteristics and all the key variables. The results revealed no significant differences between young adults who participated at $\mathrm{T} 1$ and $\mathrm{T} 2$ and those who responded only at T1. Therefore, we concluded that attrition had no effect on the results. Finally, we used the expectationmaximisation (EM) method to estimate missing values and the result of Little's missing completely at random (MCAR) test was not statistically significant, $\chi(38)=$ 43.25, $p=0.257$.

\section{Data Analysis}

All analyses were conducted in SPSS Statistics Version 25. First, we examined the descriptive information and the correlations between all the study variables. Next, we used serial mediation analysis to examine the multiple mediating pathways between life satisfaction and tolerance via political satisfaction and social trust among native young adults. Serial mediation analysis allows the testing of multiple mediators simultaneously (i.e., the total indirect effect) while controlling for both collinearity and mediational effects. For this purpose, we applied the SPSS macro PROCESS (Model 6; Hayes, 2013) with two mediators (i.e., political satisfaction and social trust). The bootstrapping method was used to test for the significance of the effects in order to obtain robust standard errors for parameter estimation. Bootstrapping is considered the most powerful and effective method for estimating the significance of indirect effects, makes no assumptions about normality in the sampling distribution and has superior control 
over Type 1 errors (Preacher \& Hayes, 2004). In our study, we utilised 5000 bootstrap estimates for the construction of $95 \%$ bias-corrected confidence intervals (CIs) for the effect estimates. We used CIs rather than the point estimate (or probability value) in evaluating the significance of the mediating effects. The effects were statistically significant if the $95 \%$ bias-corrected CIs did not include zero. In the serial mediation analysis, we controlled for participants' gender, educational level, perceived SES and tolerance at $\mathrm{T} 1$.

\section{Results}

\section{Preliminary Analyses}

Means, standard deviations and correlations between the study variables are presented in Table 1 . As can be seen in the table, educational level, life satisfaction, political satisfaction and social trust were positively associated with tolerance towards immigrants as well as of each other. Preliminary analyses also revealed that female participants reported higher levels of tolerance than male $(t(1376)=7.37, p<0.001,95 \% \mathrm{CI}=[0.19,0.33])$, had higher political satisfaction $(t(1376)=3.20, p<0.001$, $95 \% \mathrm{CI}=[0.06,0.27])$, and had higher social trust $(t(1376)=2.66, p<0.001,95 \% \mathrm{CI}=[0.03,0.21])$. In addition, young adults who reported higher SES also reported higher levels of life satisfaction $(t(1372)=-6.40$, $p<0.001,95 \% \mathrm{CI}=[-0.31,-0.16])$, higher political satisfaction $(t(1372)=-12.35, p<0.05,95 \% \mathrm{CI}=[-0.83$, $-0.60])$ and higher social trust $(t(1372)=-6.23, p<0.05$, $95 \% \mathrm{CI}=[-0.46,-0.24])$, as compared with those identifying as lower SES.

\section{Serial Mediation Analysis}

The serial mediation analysis examined whether the relationship between life satisfaction and tolerance towards immigrants would be mediated via political satisfaction and social trust. The serial mediation model (see Fig. 2) showed that life satisfaction had a significant positive effect on both political satisfaction $(B=0.18, S E=0.02, t=8.69, p<0.001,95 \% \mathrm{CI}$ $[0.14,0.21])$ and social trust $(B=0.17, S E=0.03, t=5.70$, $p<0.001,95 \%$ CI $[0.11,0.23])$. Further, political satisfaction was significantly positively related to social trust $(B=0.26$, $S E=0.05, t=5.77, p<0.001,95 \%$ CI $[0.17,0.35])$ but not to tolerance towards immigrants $(B=0.02, S E=0.03, t=$ $0.72, p=0.47,95 \% \mathrm{CI}[-0.03,0.07])$. In addition, social trust had a significant positive effect on tolerance towards immigrants $(B=0.05, S E=0.02, t=2.52, p<0.01,95 \%$ CI $[0.01$, $0.08]$ ). Finally, there was no statistically significant direct effect of life satisfaction on tolerance towards immigrants $(B=$ $-0.01, S E=0.02, t=-0.74, p=46,95 \%$ CI $[-0.05,0.02])$. Therefore, the results indicate that native majority youth who reported high levels of life satisfaction were also more likely to display political satisfaction and social trust, which was positively related to their tolerance towards immigrants two years later.

The analysis also revealed that the specific indirect effect of life satisfaction on tolerance towards immigrants via political satisfaction $(B=0.003, S E=0.005, p>0.05,95 \%$ CI $[-0.006$, 0.013]) was non-significant; yet the specific indirect effect via social trust $(B=0.008, S E=0.004, p<0.05,95 \%$ CI $[0.002$, $0.016])$ was significant. Next, the serial mediation effect of life satisfaction on tolerance towards immigrants via both political satisfaction and social trust $(B=0.002, S E=0.001 p<0.05$, $95 \% \mathrm{CI}[0.001,0.004])$ was significant. In addition, the total indirect effect $(B=0.014, S E=0.006 p<0.05,95 \%$ CI
Table 1 Correlations, means and standard deviations for the study variables

\begin{tabular}{lllllllll}
\hline & 1 & 2 & 3 & 4 & 5 & 6 & 7 & 8 \\
\hline 1. Gender & - & & & & & & \\
2. Educational level & $-0.14^{* *}$ & - & & & & & \\
3. Perceived SES & -0.01 & $-0.06^{*}$ & - & & & & \\
4. Tolerance - T1 & $-0.18^{* *}$ & $0.25^{* *}$ & 0.03 & - & & & & \\
5. Life satisfaction & -0.09 & $0.13^{* *}$ & $0.32^{* *}$ & $0.09^{* *}$ & - & & \\
6. Political satisfaction & $-0.07^{*}$ & $0.07^{* *}$ & $0.17^{* *}$ & $0.14^{* *}$ & $0.30^{* *}$ & - & \\
7. Social trust & -0.05 & $0.15^{* *}$ & $0.17^{* *}$ & $0.29^{* *}$ & $0.31^{* *}$ & $0.27^{* *}$ & - & \\
8. Tolerance - T2 & $-0.18^{* *}$ & $0.20^{* *}$ & 0.05 & $0.73^{* *}$ & $0.09^{* *}$ & $0.11^{* *}$ & $0.27^{* *}$ & - \\
$M$ & - & 4.48 & 1.77 & 3.18 & 5.27 & 2.72 & 3.24 & 3.24 \\
$S D$ & - & 1.48 & 0.42 & 0.70 & 0.96 & 0.59 & 0.89 & 0.70 \\
\hline
\end{tabular}

$* p<.05 ;{ }^{* *} p<.01$

T1 refers to the Time 1 assessment and T2 to the Time 2 assessment. Gender was coded as: ' 1 ' female and ' 2 ' male 
Fig. 2 Mediation model: Political satisfaction and social trust as mediators between life satisfaction and tolerance toward immigrants. Note: Values outside parentheses indicate unstandardised regression coefficients $(B)$; values in parentheses indicate standard errors $(S E)$. Dotted lines indicate insignificant paths. Demographic variables (gender, educational level, SES) are not displayed for clarity. $* * p<.01 ; * * * p<.001$

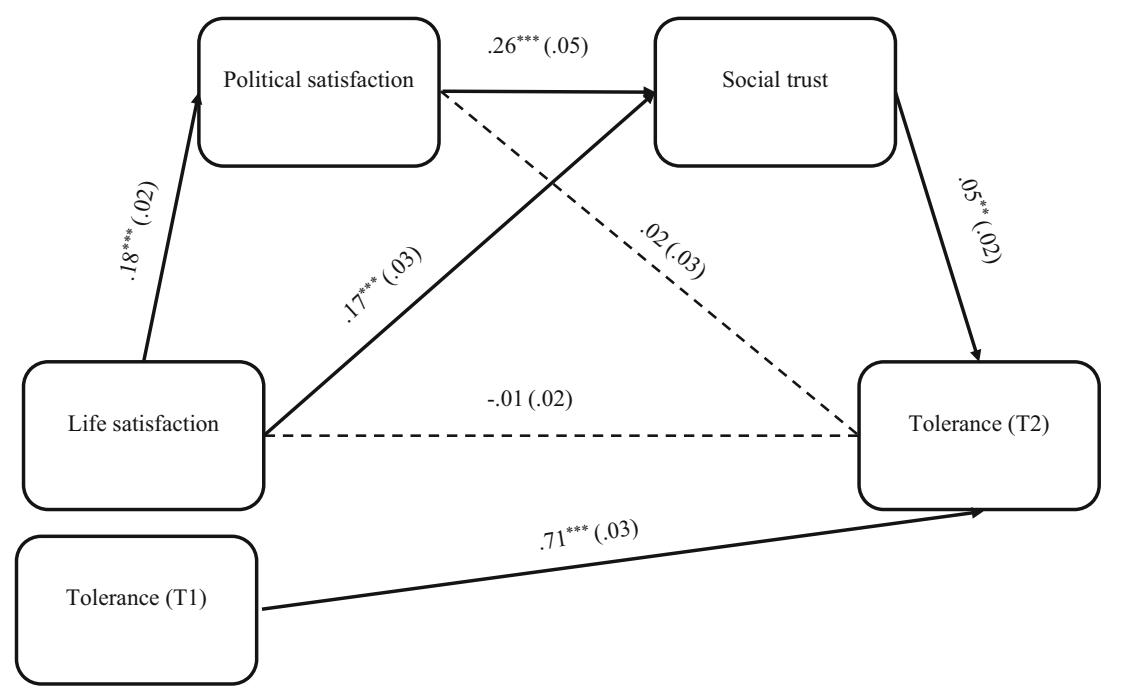

$[0.002,0.026])$ was also found to be significant. The total amount of variance accounted for by the overall serial mediation model was $53.50 \%$. Thus, the serial mediation analysis revealed that the relationship between life satisfaction and tolerance towards immigrants was fully mediated via political satisfaction and social trust. Taken together, the results showed that native majority youth's life satisfaction positively predicted tolerance towards immigrants through the sequential increase of their political satisfaction and social trust.

We also ran an alternative serial mediation analysis to examine the relationship from life satisfaction to social trust to political satisfaction to tolerance towards immigrants. Yet, the serial mediation effect via social trust and political satisfaction $(B=0.0005, S E=0.0008, p>0.05,95 \%$ CI $[-0.0011$, $0.0021])$ was found to be non-significant. Overall, we conclude that there is robust statistical evidence for the positive effect of life satisfaction on tolerance towards immigrants through the sequential relationship between political satisfaction and social trust.

\section{Discussion}

European societies, including Sweden, are becoming more ethnically and culturally diverse as a result of an influx of immigrants, refugees and asylum-seekers across its national borders. Despite the positive effects of immigration on European states - such as increasing the number of people of working age willing to take on low-paid jobs and providing extra taxes for an economy (Eurofound and International Labour Organization, 2019) - xenophobia and antiimmigrant sentiments are on the rise among the EU native population (Bevelander \& Wodak, 2019). This trend of growing intolerance is particularly evident among young people, who face increasing insecurity on the labour market (Mierina \& Koroḷeva, 2015) and greater competition from immigrants in areas such as the employment and housing markets (Janmaat \& Keating, 2019). Such a hostile and unwelcoming environment threatens the harmonious integration of newcomers into a host society and might have detrimental consequences for the social cohesion and future prospects of the immigrant-receiving countries. Although research has gone a long way towards understanding the determinants of antiimmigrant attitudes, little is known about what might promote positive attitudes towards immigrants in young adulthood. To fill this gap in the existing knowledge, the present study was designed to clarify the role of life satisfaction in shaping tolerance towards immigrants among native young adults. Specifically, we examined the over-time effect of life satisfaction on tolerance towards immigrants while considering the mediating roles of political satisfaction and social trust simultaneously.

Consistent with our initial expectations and prior research in the field (e.g., Gordon, 2018; Sirgy et al., 2018), the present study showed that life satisfaction has important implications for the adoption of positive attitudes towards immigrants. In particular, we found that the specific indirect effect of life satisfaction on tolerance towards immigrants via both political satisfaction and social trust was significantly positive. Supporting our hypothesis, the study showed that the positive impact of life satisfaction on tolerance towards immigrants occurs through a process in which political satisfaction increases social trust which, in turn, leads to more positive perceptions of immigrants. In other words, this finding indicates that native young adults who are satisfied with important life domains - and life as a whole - are more likely to extend their satisfaction to the political system, which consequently results in a generalised expectation of trustworthiness and the widening of their circles of trusted others, translating into more positive attitudes towards immigrants. These findings are in line with prior research that highlights the importance of subjective well-being in facilitating supporting attitudes towards 
the broader society (e.g., Esaiasson et al., 2019; Hooghe, 2012) and building trusting relationships with others (e.g., Helliwell \& Putnam, 2004; Valenzuela et al., 2009; Zanin, 2017) as well as the implications of political satisfaction and social trust for attitudes towards immigrants (e.g., Aschauer, 2016; Herreros \& Criado, 2009; van Linden et al., 2017).

It warrants mention that the specific indirect effect of life satisfaction on tolerance towards immigrants via political satisfaction was found to be non-significant. This finding reveals that, although life satisfaction exerts a positive impact on political satisfaction, this positive influence does not translate into tolerance towards immigrants unless it is followed by social trust. Hence, political satisfaction does not directly lead to more positive attitudes towards immigrants but, rather, has an indirect influence via an increase in social trust. The results support previous findings about the significant role of both political and social trust as major determinants of people's attitudes towards immigrants (e.g., Halapuu et al., 2014), and also add to prior research showing the causal link between institutional and interpersonal trust (e.g., Sønderskov \& Dinesen, 2014, 2016). At the same time, the significance of another specific indirect influence of life satisfaction on tolerance towards immigrants only via social trust demonstrates that high life satisfaction promotes positive attitudes towards immigrants by triggering trusting relationships with others. This finding underscores the important role of interpersonal social trust propelled by high life satisfaction in shaping tolerance towards immigrants.

The results obtained might imply that the over-time role of life satisfaction in promoting positive attitudes toward immigrants is better explained by an increase in social trust among young adults rather than by an increase in their political satisfaction. Nonetheless, the significance of the serial multiple mediating effect (i.e., via both political satisfaction and social trust) indicates that this relationship is more complex than independent additive effects. Specifically, this finding demonstrates that the mediating role that social trust plays in the relationship between life satisfaction and tolerance towards immigrants might be particularly due to its causal link with political satisfaction. To put it another way, the findings provide meaningful evidence that it is the causal relationship between political satisfaction and social trust (rather than social trust by itself) that promotes the positive impact of life satisfaction on shaping tolerance towards immigrants.

\section{Strengths, Limitations and Future Directions}

The research presented here has a number of major strengths. It is the first study to examine the role of native majority youth's life satisfaction in promoting tolerance towards immigrants in the longitudinal perspective. Thus far, the relationship between subjective well-being and attitudes towards immigrants received support from cross-sectional research. This study is also the first to provide an insight into the potential underlying mechanisms that might link high life satisfaction with positive attitudes towards immigrants over time. Specifically, our findings provide evidence that high levels of life satisfaction lead to tolerance towards immigrants via their increased political satisfaction and sequentially increased social trust (rather than only social trust by itself). Moreover, the important contribution of this study is that, unlike much prior research in the field, it examines positive attitudes towards immigrants as a separate construct (independently from negative attitudes towards immigrants). Finally, the current study focuses on the role of life satisfaction in shaping tolerance towards immigrants in young adulthood where the research is still scarce. Thus, its findings contribute to our understanding of what might promote positive attitudes towards immigrant-origin individuals during this important stage of human development when outgroup attitudes still continue to crystalise (Henry \& Sears, 2009).

Our findings should be viewed in the light of the present study's potential limitations. First, while analysing tolerance towards immigrants we captured only the attitudinal dimension. At the same time, we acknowledge that the conceptualisation of tolerance could be broader and also include a behavioural dimension. Future studies may need to apply more varied measurement strategies in order to understand the impact of life satisfaction on different dimensions of tolerance towards immigrants. Second, the use of self-reporting questionnaires may have caused the data to be susceptible to social desirability and response biases. Future research could eliminate this possibility by supplementing the self-reported measures with other informant reports (e.g., from family members or friends) or by including a social desirability bias scale as a control variable.

Third, the present study is based on the data collected from a single city in Sweden. The sample is fairly similar in demographic characteristics to the national average (e.g. in terms of income, level of education, etc.). Nonetheless, we cannot say that the findings are valid for young adults in other countries. The existing literature suggests that young people's experiences of life satisfaction are embedded in specific sociocultural contexts (Diener \& Oishi, 2004; Tov \& Diener, 2009) and vary between nations with different levels of development (Diener et al., 2010). Therefore, the findings reported here need to be cross-validated in other national and cultural contexts. Fourth, this study has focused on the role of life satisfaction in shaping tolerance towards immigrants via political satisfaction and social trust among native young adults. Future research may contribute to the literature by examining whether the results obtained could also apply to representatives of ethnic-minority groups. Finally, the current study has attempted to explore the mediating mechanisms in the link between life satisfaction and tolerance towards immigrants, although future studies should also examine the moderating 
conditions (for example, friendships with immigrant-origin individuals) of this complex relationship.

\section{Conclusions and Implications}

Much prior research relies on the idea that antipathy towards immigrants is primarily driven by natives' perceptions of the threat that immigrants represent to their economic, cultural or national well-being. Yet, little is known about whether subjective well-being affects attitudes towards immigrants. To move the current research frontier forward, the present study aimed to examine the potential role that life satisfaction might have to play in promoting tolerance towards immigrants among native majority youth in Sweden. Our research findings suggest that native young adults with high life satisfaction are more prone to exhibit satisfaction with the democracy and political actors in the country which, in turn, makes them more likely to widen their circles of trusted others and triggers more positive attitudes towards immigrants. The evidence provided by the present study indicates that monitoring and increasing young people's subjective well-being - and their life satisfaction in particular - is important for improving their views and perceptions of immigrant-origin individuals. A large body of prior research in positive psychology has recommended a variety of ways to enhance youth's life satisfaction through cultivating positive cognition, feelings and behaviours (for reviews, see, for example, Allen, 2018; Sin \& Lyubomirsky, 2009). These strategies may serve as a basis for developing new programmes that aim to promote tolerance through enhancing life satisfaction among young adults. Moreover, as suggested by our findings, these programmes may become more successful through integrating components designed to enhance political satisfaction and social trust as important mechanisms in shaping young people's positive attitudes towards immigrants. Overall, the study opens up new possibilities of promoting youth's tolerance towards immigrants as well as appreciation of ethnic and cultural diversity among native majority individuals.

Acknowledgements This publication resulted (in part) from research supported by the grant from the Beatriu de Pinós Programme, funded by the Direcció General de Recerca de la Generalitat de Catalunya (General Directorate for Research in the Government of Catalonia) and co-funded by the European Union through the COFUND programme (contract number 801370) for Marie-Skłodowska-Curie actions in the "Horizon 2020" programme.

This study was made possible by access to data from the Political Socialization Program, a longitudinal research programme at YeS (Youth \& Society) at Örebro University, Sweden. Responsible for the planning, implementation, and financing of the collection of data were professors Erik Amnå, Mats Ekström, Margaret Kerr, and Håkan Stattin. The data collection was supported by grants from Riksbankens Jubileumsfond. The authors received permission to use the data for the current study from Håkan Stattin.
Funding Open access funding provided by Malmö University.

Data Availability The data generated and/or analyzed during the current study are not publicly available.

\section{Declarations}

Ethical Approval The Regional Research Ethics Committee in Uppsala approved the study procedures.

Informed Consent All participants were informed about the study procedure and consented to take part in the study.

Declaration of Conflicting Interests The authors declared no potential conflicts of interest with respect to the research, authorship, and/or publication of this article.

Open Access This article is licensed under a Creative Commons Attribution 4.0 International License, which permits use, sharing, adaptation, distribution and reproduction in any medium or format, as long as you give appropriate credit to the original author(s) and the source, provide a link to the Creative Commons licence, and indicate if changes were made. The images or other third party material in this article are included in the article's Creative Commons licence, unless indicated otherwise in a credit line to the material. If material is not included in the article's Creative Commons licence and your intended use is not permitted by statutory regulation or exceeds the permitted use, you will need to obtain permission directly from the copyright holder. To view a copy of this licence, visit http://creativecommons.org/licenses/by/4.0/.

\section{References}

Aknin, L. B., Van de Vondervoort, J. W., \& Hamlin, K. J. (2018). Positive feelings reward and promote prosocial behavior. Current Opinion in Psychology, 20, 55-59. https://doi.org/10.1016/j.copsyc. 2017.08.017.

Allen, J. B. (2018). The psychology of happiness in the modern world: A social psychological approach. Springer.

Amnå, E., Ekström, M., Kerr, M., \& Stattin, H. (2009). Political socialization and human agency: The development of civic engagement from adolescence to adulthood. Statsvetenskaplig Tidskrift, 111(1), $27-40$.

Ariely, G. (2012). Globalisation and the decline of national identity? An exploration across sixty-three countries. Nations and Nationalism, 18(3), 461-482. https://doi.org/10.1111/j.1469-8129.2011.00532.x.

Arnett, J. J. (2015). Emerging adulthood: The winding road from the late teens through the twenties (2nd ed.). Oxford University Press.

Aschauer, W. (2016). Societal malaise and ethnocentrism in the European Union: Monitoring societal change by focusing on EU citizens' perceptions of crisis. Historical Social Research/Historische Sozialforschung, 41(2), 307-359. https://doi.org/10.12759/hsr.41. 2016.2.307-359.

Bélanger, É., \& Nadeau, R. (2005). Political trust and the vote in multiparty elections: The Canadian case. European Journal of Political Research, 44(1), 121-146. https://doi.org/10.1111/j.1475-6765. 2005.00221.x.

Bevelander, P., \& Hellström, A. (2019). Citizens to stay. Pro- and antimigrant mobilizations in polarized Sweden. In A. Rea, M. Martiniello, A. Mazzola, P. DeCuyper, \& B. Meuleman (Eds.), The refugee reception crisis in anti-immigrant times. Polarization 
of the public opinion, local mobilizations and reception practices in Europe (pp. 75-94). ULB Press-European Studies.

Bevelander, P., \& Wodak, R. (Eds.). (2019). Europe at the crossroads: Confronting populist, nationalist and global challenges. Nordic Academic Press.

Branscombe, N. R., \& Wann, D. L. (1992). Role of identification with a group, arousal, categorization processes, and self-esteem in sports spectator aggression. Human Relations, 45(10), 1013-1033. https:// doi.org/10.1177/001872679204501001.

Brehm, J., \& Rahn, W. (1997). Individual-level evidence for the causes and consequences of social capital. American Journal of Political Science, 41(3), 999-1023. https://doi.org/10.2307/2111684.

Brown, R. (2011). Prejudice: Its social psychology. Wiley-Blackwell.

Demker, M. (2014). Sverige åt svenskarna: Motstånd och mobilisering mot invandring och invandrare i Sverige. (Göteborg Studies in Politics, no. 135). Atlas.

Diener, E., \& Oishi, S. (2004). Are Scandinavians happier than Asians? Issues in comparing nations on subjective well-being. In F. Columbus (Ed.), Asian economic and political issues, 10 (pp. 125). Nova Science.

Diener, E., Kahneman, D., Tov, W., \& Arora, R. (2010). Income's association with judgments of life versus feelings. In E. Diener, J. Helliwell, \& D. Kahneman (Eds.), International differences in well-being (pp. 3-15). Oxford University Press. https://doi.org/10. 1093/acprof:oso/9780199732739.003.0001.

Dunn, J. R., \& Schweitzer, M. E. (2005). Feeling and believing: The influence of emotion on trust. Journal of Personality and Social Psychology, 88(5), 736-748. https://doi.org/10.1037/0022-3514.88.5.736.

Emilsson, H. (2018). Continuity or change? The refugee crisis and the end of Swedish exceptionalism. MIM Working Paper Series, 18(3), 1-22.

Esaiasson, P., Dahlberg, S., \& Kokkonen, A. (2019). In pursuit of happiness: Life satisfaction drives political support. European Journal of Political Research, 59, 25-44. https://doi.org/10.1111/1475-6765.12335.

Eurofound and International Labour Organization. (2019). Working conditions in a global perspective. In Luxembourg: Publications office of the European union. International Labour Organization Retrieved from $\mathrm{http} / / /$ eurofound.link/ef18066.

Eurostat (2020). Retrieved from https://ec.europa.eu/eurostat/statisticsexplained/index.php/Quality of life indicators - overall experience_of_life

Forgas, J. P., \& George, J. M. (2001). Affective influences on judgments, decision making and behavior in organizations: An information processing perspective. Organizational Behavior and Human Decision Processes, 86(1), 3-34. https://doi.org/10.1006/obhd.2001.2971.

Fredrickson, B. L. (2001). The role of positive emotions in positive psychology: The broaden-and-build theory of positive emotions. American Psychologist, 56(3), 218-226. https://doi.org/10.1037/ 0003-066X.56.3.218.

Gordon, S. L. (2018). Understanding evaluations of foreigners in modern South Africa: The relationship between subjective wellbeing and xenophobia. Journal of Happiness Studies, 19(2), 545-566. https://doi.org/10.1007/s10902-016-9838-6.

Hainmueller, J., \& Hiscox, M. J. (2007). Educated preferences: Explaining attitudes toward immigration in Europe. International Organization, 61(2), 399-442. https://doi.org/10.1017/ S0020818307070142.

Halapuu, V., Paas, T., \& Tammaru, T. (2014) Is institutional trust related to the attitudes towards immigrants in Europe? A study of majority and minority population. Norface migration discussion paper (no. 2013-14). London. Retrieved from https://ideas.repec.org/p/nor/ wpaper/2013014.html

Hayes, A. F. (2013). Introduction to mediation, moderation, and conditional process analysis. Guilford Press.

Helliwell, J. F., \& Putnam, R. D. (2004). The social context of well-being. The Royal Society, 359(1449), 1435-1446. https://doi.org/10.1098/ rstb.2004.1522.
Henry, P. J., \& Sears, D. O. (2009). The crystallization of contemporary racial prejudice across the lifespan. Political Psychology, 30(4), 569-589. https://doi.org/10.1111/j.1467-9221.2009.00715.x.

Herreros, F., \& Criado, H. (2009). Social trust, social capital and perceptions of immigration. Political Studies, 57(2), 337-355. https://doi. org/10.1111/j.1467-9248.2008.00738.x.

Hooghe, M. (2012). I'm happy, hope you're happy too: Examining the different dynamics of individual subjective well-being and views on society. Journal of Happiness Studies, 13(1), 17-29. https://doi.org/ 10.1007/s10902-011-9247-9.

Isen, A. M., \& Baron, R. (1991). Positive affect as a factor in organizational behavior. In L. L. Cummings \& B. W. Staw (Eds.), Research in organizational behavior (Vol. 13, pp. 1-53). JAI Press.

Janmaat, J., \& Keating, A. (2019). Are today's youth more tolerant? Trends in tolerance among young people in Britain. Ethnicities, 19(1), 44-65. https://doi.org/10.1177/1468796817723682.

Jetten, J., Mols, F., \& Postmes, T. (2015). Relative deprivation and relative wealth enhances anti-immigrant sentiments: The V-curve reexamined. PLoS One, 10(10), e0139156. https://doi.org/10.1371/ journal.pone.0139156.

Korol, L. (2019). Does multicultural personality moderate the relationship between cross-group friendship and allophilia? The Journal of Social Psychology, 159(6), 649-663. https://doi.org/10.1080/ 00224545.2018.1549012.

Korol, L., Fietzer, A. W., \& Ponterotto, J. G. (2018). Relationship between multicultural personality, intergroup contact, and positive outgroup attitudes toward Asian Americans. Asian American Journal of Psychology, 9(3), 200-210. https://doi.org/10.1037/ aap0000107.

Kumlin, S., \& Rothstein, B. (2005). Making and breaking social capital: The impact of welfare-state institutions. Comparative Political Studies, 38, 339-365. https://doi.org/10.1177/0010414004273203.

Lancee, B., \& Sarrasin, O. (2015). Educated preferences or selection effects? A longitudinal analysis of the impact of educational attainment on attitudes towards immigrants. European Sociological Review, 31(4), 490-501. https://doi.org/10.1093/esr/jcv008.

Lyubomirsky, S., King, L., \& Diener, E. (2005). The benefits of frequent positive affect: Does happiness leads to success? Psychological Bulletin, 131(6), 803-855. https://doi.org/10.1037/0033-2909.131.6.803.

Mattila, M., \& Rapeli, L. (2018). Just sick of it? Health and political trust in Western Europe. European Journal of Political Research, 57(1), 116-134. https://doi.org/10.1111/1475-6765.12218.

Mayseless, O., \& Karen, E. (2014). Finding a meaningful life as a developmental task in emerging adulthood: The domains of love and work across cultures. Emerging Adulthood, 2(1), 63-73. https:// doi.org/10.1177/2167696813515446.

McLaren, L. M. (2003). Anti-immigrant prejudice in Europe: Contact, threat perception, and preferences for the exclusion of migrants. Social Forces, 81(3), 909-936. https://doi.org/10.1353/sof.2003.0038.

McLaren, L., \& Johnson, M. (2007). Resources, group conflict and symbols: Explaining anti-immigration hostility in Britain. Political Studies, 55(4), 709-732. https://doi.org/10.1111/j.1467-9248.2007.00680.x.

Mierina, I., \& Korol̦eva, I. (2015). Support for far-right ideology and antimigrant attitudes among youth in Europe: A comparative analysis. The Sociological Review, 63(2), 183-205. https://doi.org/10.1111/ 1467-954X.12268.

Newton, K., \& Zmerli, S. (2011). Three forms of trust and their association. European Political Science Review, 3(2), 169-200. https://doi. org/10.1017/S1755773910000330.

Newton, K., Stolle, D., \& Zmerli, S. (2018). Social and political trust. In E. M. Uslaner (Ed.), The Oxford handbook of social and political trust (pp. 37-56). Oxford University Press.

Oishi, S., Diener, E., \& Lucas, R. E. (2007). The optimum level of wellbeing: Can people be too happy? Perspectives on Psychological Science, 2(4), 346-360. https://doi.org/10.1111/j.1745-6916.2007. 00048.x. 
Panno, A. (2018). Social dominance and attitude towards immigrants: The key role of happiness. Social Sciences, 7(8), 126. https://doi. org $/ 10.3390 /$ socsci7080126.

Preacher, K. J., \& Hayes, A. F. (2004). SPSS and SAS procedures for estimating indirect effects in simple mediation models. Behavior Research Methods, Instruments, \& Computers, 36, 717-731. https://doi.org/10.3758/BF03206553.

Pryce, D. K. (2018). U.S. citizens' current attitudes toward immigrants and immigration: A study from the general social survey. Social Science Quarterly, 99(4), 1467-1483. https://oi.org/10.1111/ssqu.12514.

Putnam, R. D. (2000). Bowling alone: The collapse and revival of American community. Simon and Schuster.

Quillian, L. (1995). Prejudice as a response to perceived group threat: Population composition and anti-immigrant and racial prejudice in Europe. American Sociological Review, 60(4), 586-611. https://doi. org/10.2307/2096296.

Rothstein, B. (2001). Social capital in the social democratic welfare state. Politics and Society, 29(2), 207-241. https://doi.org/10.1177/ 0032329201029002003.

Rothstein, B., \& Stolle, D. (2008). Political institutions and generalized trust. In D. Castiglione, J. W. van Deth, \& G. Wolleb (Eds.), The handbook of social capital (pp. 273-302). Oxford University Press.

Rubin, B. (2012). Shifting social contracts and the sociological imagination. Social Forces, 91(2), 327-346. https://doi.org/10.2307/ 23361092.

Rydgren, J., \& van der Meiden, S. (2019). The radical right and the end of Swedish exceptionalism. European Political Science, 18(3), 439455. https://doi.org/10.1057/s41304-018-0159-6.

Schneider, S. L. (2008). Anti-immigrant attitudes in Europe: Outgroup size and perceived ethnic threat. European Sociological Review, 24(1), 53-67. https://doi.org/10.1093/esr/jcm034.

Schwarz, N. (1990). Feelings as information: Informational and motivational functions of affective states. In E. T. Higgins \& R. Sorrentino (Eds.), Handbook of motivation and cognition: Foundations of social behavior (Vol. 2, pp. 527-561). Guilford Press.

Schwarz, N., \& Clore, G. L. (1988). How do I feel about it? Informative functions of affective states. In K. Fiedler \& J. Forgas (Eds.), Affect, cognition, and social behavior (pp. 44-62). Hogrefe.

Semyonov, M., \& Glikman, A. (2009). Ethnic residential segregation, social contacts, and anti-minority attitudes in European societies. European Sociological Review, 25(6), 693-708. https://doi.org/10. 1093/esr/jen075.

Sides, J., \& Citrin, J. (2007). European opinion about immigration: The role of identities, interests, and information. British Journal of Political Science, 37(3), 477-504. https://doi.org/10.1017/ S0007123407000257.

Sin, N. L., \& Lyubomirsky, S. (2009). Enhancing well-being and alleviating depressive symptoms with positive psychology interventions: A practice-friendly meta-analysis. Journal of Clinical Psychology, 65(5), 467-487. https://doi.org/10.1002/jclp.20593.

Sirgy, M. J., Kim, M. Y., Joshanloo, M., \& Bosnjak, M. (2018). Is subjective ill-being related to islamophobia in Germany? In search for moderators. Journal of Happiness Studies, 20(2019), 2655-2675. https://doi.org/10.1007/s10902-018-0063-3.

Sønderskov, K. M., \& Dinesen, P. T. (2014). Danish exceptionalism: Explaining the unique increase in social trust over the past 30 years. European Sociological Review, 30(6), 782-795. https://doi.org/10. 1093/esr/jcu073.

Sønderskov, K. M., \& Dinesen, P. T. (2016). Trusting the state, trusting each other? The effect of institutional trust on social trust. Political Behavior, 38, 179-202. https://doi.org/10.1007/s11109-015-9322-8.

Statistics Sweden (2020). Retrieved from https://www.scb.se/hittastatistik/sverige-i-siffror/manniskorna-i-sverige/utrikes-fodda/
Statistiska Centralbyrån (2019). Retrieved from http://www. statistikdatabasen.scb.se/pxweb/sv/ssd/?rxide1e1ad6f-5291-43248193-88b3c93bb864

Tao, R., Yang, D. L., Li, M., \& Lu, X. (2014). How does political trust affect social trust? An analysis of survey data from rural China using an instrumental variables approach. International Political Science Review, 35(2), 237-253. https://doi.org/10.1177/ 0192512113492599.

Tenenbaum, H., Capelos, T., Lorimer, J., \& Stocks, T. (2018). Positive thinking elevates tolerance: Experimental effects of happiness on adolescents' attitudes towards asylum seekers. Clinical Child Psychology and Psychiatry, 23(2), 346-357. https://doi.org/10. 1177/1359104518755217.

Tov, W., \& Diener, E. (2009). Culture and subjective well-being. In E. Diener (Ed.), Social indicators research series, Culture and wellbeing: The collected works of Ed Diener (Vol. 38, pp. 9-41). Springer Science + Business Media.

Unanue, W., Gomez Mella, M. E., Cortez, D. A., Bravo, D., Araya-Véliz, C., Unanue, J., \& Van Den Broeck, A. (2019). The reciprocal relationship between gratitude and life satisfaction: Evidence from two longitudinal field studies. Frontiers in Psychology, 10, 2480. https:// doi.org/10.3389/fpsyg.2019.02480.

Valenzuela, S., Par, N., \& Kee, K. F. (2009). Is there social capital in a social network site? Facebook use and college students' life satisfaction, trust, and participations. Journal of Computer-Mediated Communication, 14(4), 875-901. https://doi.org/10.1111/j.10836101.2009.01474.x.

Van Linden, M., Hooghe, M., de Vroome, T., \& Van Laar, C. (2017). Extending trust to immigrants: Generalized trust, cross-group friendship and anti-immigrant sentiments in 21 European societies. PLoS One, 12(5), e0177369. https://doi.org/10.1371/journal.pone.0177369.

Van Zalk, M. H., \& Kerr, M. (2014). Developmental trajectories of prejudice and tolerance toward immigrants from early to late adolescence. Journal of Youth and Adolescence, 43(10), 1658-1671. https://doi.org/10.1007/s10964-014-0164-1.

Van Zalk, M. H. W., Kerr, M., Van Zalk, N., \& Stattin, H. (2013). Xenophobia and tolerance toward immigrants in adolescence: Cross-influence processes within friendships. Journal of Abnormal Child Psychology, 41(4), 627-639. https://doi.org/10.1007/s10802012-9694-8.

Vittersø, J., \& Søholt, Y. (2011). Life satisfaction goes with pleasure and personal growth goes with interest: Further arguments for separating hedonic and eudaimonic wellbeing. The Journal of Positive Psychology, 6(4), 326-335. https://doi.org/10.1080/17439760. 2011.584548.

Walker, I., \& Smith, H. (Eds.). (2002). Relative deprivation: Specification, development and integration. Cambridge University Press.

Wroe, A. (2014). Political trust and job insecurity in 18 European polities. Journal of Trust Research, 4(2), 90-112. https://doi.org/10.1080/ 21515581.2014.957291.

You, J. S. (2012). Social trust: Fairness matters more than homogeneity. Political Psychology, 33(5), 701-721. https://doi.org/10.1111/j. 1467-9221.2012.00893.x.

Zanin, L. (2017). Education and life satisfaction in relation to the probability of social trust: A conceptual framework and empirical analysis. Social Indicators Research, 132(2), 925-947. https://doi.org/10. 1007/s11205-016-1322-5.

Zmerli, S., \& Newton, K. (2008). Social trust and attitudes toward democracy. Public Opinion Quarterly, 72(4), 706-724. https://doi.org/ 10.1093/poq/nfn054.

Publisher's Note Springer Nature remains neutral with regard to jurisdictional claims in published maps and institutional affiliations. 